January 2018

\title{
Impact of divorce on students' life
}

Laila Akber Cassum

Aga Khan University School of Nursing and Midwifery (AKUSONAM), laila.cassum@aku.edu

Follow this and additional works at: https://ecommons.aku.edu/pakistan_fhs_son

Part of the Nursing Midwifery Commons

\section{Recommended Citation}

Cassum, L. A. (2018). Impact of divorce on students' life. i-manager's Journal on Educational Psychology, 11(4), 54-58.

Available at: https://ecommons.aku.edu/pakistan_fhs_son/330 


\section{IMPACT OF DIVORCE ON STUDENTS' LIFE}

By

\section{LAILA AKBER CASSUM}

Senior Instructor, Aga Khan University School of Nursing and Midwifery (AKUSONAM), Pakistan.

\section{ABSTRACT}

Tension and anxiety is the common phenomena among the students of modern generation. These students go through stress due to personal, psychosocial, familial, and academic matters. Some of the common ones which substantially impact their lives like family disputes, academic challenges, parental conflicts, financial concerns, social isolation and interpersonal matters, parental separation and divorce, separation from family, and reduced support system. Untiring conflicts between the parents weaken the lifelong marriage contract to the verge of breakdown, where both the life partners determine to go for the option of divorce. This creates traumatic and nerve wracking atmosphere at home and the children are mostly affected by this decision and are torn between the parents. They undergo persistent mental pressure, which can have substantial physical, psychological, psychosocial impact on the student's wellbeing as well as on their academic performance graph.

Keywords: Parental Relations, Divorce, Student's Life, Psychological Impact, Academic Impact.

\section{INTRODUCTION}

Stress is a natural phenomenon which is experienced by everyone throughout their daily lives. Everyone's life is packaged with day to day challenges and confronting those experiences successfully, highly count on the ability to recuperate from those stressors. In recent years, stress and anxieties are predominant among the millennial generation students. Students go through stress due to various issues like family disputes, academic challenges, parental conflicts, financial concerns, social isolation, and interpersonal matters. Some have strong coping mechanism to muddle through it while others require time and coping to manage the situation. Stressful circumstances can have constructive and destructive effects on the health and disrupt the quality of life of an individual. Tireless tension during student life can largely impact on the mental health, learning and quality of life of the students (Kleiveland et al., 2010; Melo et al., 2010). Breakdown of the parental relationship can be one of the major factors of psychosocial stress among the students. This paper primarily focuses on parental conflicts ending up into divorce that can adversely impact on student's psychological wellbeing and academic life.

\section{Scenario}

The author came across a student who was displaying bizarre behavior, socially isolated, and her academic performance was unsatisfactory and required much facilitation. She remained mute during the class timings and preferred to sit in class and avoided social gathering of friends during the break time. Once she came to discuss her query related to the session and after responding to her, some of the critical observations were discussed with her and explored about the reasons for her behavioral change. Besides, she was encouraged her for the potentials she has, and comforted for requiring further assistance. Unpredictably, she burst out into tears, and after composing herself, she shared that she belonged to a single parent family, and lived with their maternal grandparents. She further shared that she was recently going through a mental trauma of parental divorce and the entire family members were experiencing mental stress. She also mentioned that majority of her class peers make fun of her language and accent, and nobody likes to involve her in their friend's company. Hence, she tries to 
remain socially isolated to prevent herself from further insult and damage to her self-esteem. Furthermore, she mentioned that she lacks confidence and feels insecure because of her classmates' abusive attitude and behavior. She was suggested to ventilate her feelings of negativity and guilt with any close friends, mother, or visit a counselor who could listen to her and advise some strategies to struggle with the psychological trauma.

The scenario was quite upsetting. The student was the part of the larger group, and was going through turmoil, about which the entire class was unaware, and their behavior made her feel offended, and further disturbed her mentally. The students should be subtle towards their colleagues if anyone is going through a physical or mental challenge. There were multiple questions rising that can be reflected upon: Why class colleagues behaved immaturely which made her feel insulted? How can her confidence and self-esteem can be boosted? She felt easy after regurgitating her emotions and apprehensive thoughts, which were preventing her to remain focused on her academics and perform effectively. Apart from her decline in the academic graph, the magnitude of developing psychological and behavioral effects following parental conflicts and divorce were worrisome and were deteriorating her learning capacities. Clair (n.d.) mentions that withdrawal from academic institutions can be the result of parental divorce if left unattended.

\section{Analysis of the Scenario}

The student was the victim of closure of parental relationship. As a grown adult, she has experienced the worsening of situation from her childhood, which was manifesting out in the form of behavioral problems and social isolation and seclusion. Adolescence is a significant phase in everyone's life described as a period of psychosocial confusion (Parsa et al., 2014). They are cognitively matured and capable individual than children and have high probability of involving in parental clashes and tensions (Schulz et al., 2005). On the contrary, one school of thought could be that as they mature in age they can be more resilient and adapt advanced coping mechanisms in dealing with stress due to long standing inter-parental conflicts. The resiliency is a positive trait and highly individualized, and dependent upon possessing and practicing positive coping strategies during traumatic events.

Inter-parental conflict resulting in separation or divorce is now becoming a very common social concern nowadays, and there is a substantial rise in the number of broken relationship. Divorce have substantial impact on the entire family when the lifelong marriage contract breaks up between the parents. This issue is of considerable importance due to escalating divorce rates. In Pakistan, divorce rates have risen incredibly in the last two decades and more witnessed in lower to middle class families (Khan, 2013). Approximately 124,141 cases were registered in Karachi family court from 2008-201 1 (Khan, 2013). Another statistics show that 5,000 to 6,000 divorces occur each month in Karachi. Increase in prevalence of divorce in Pakistan has also changed societal mindset about post traumatic effects of divorce in children and adults. There is a growing assumption that children are less affected through parental divorce (Rende et al., 1993). However, this hypothesis is disproved by the study outcomes, that regardless of the change in societal beliefs, it does develop devastating effects on the mental well-being (Naevdal and Thuen, 2004; Rende et al., 1993; Storksen et al., 2007). Children of the conflicting parent are torn between the parents and struggle in their academic life due to stress of undergoing parental separation.

\section{Consequences of Divorce}

Several research studies prove that the effects of parental divorce on university or college students are highly dominated by the studies conducted to explore the impact on adolescents. The students in their university life who experience lack of parental support due to family and interpersonal conflicts, struggle through lot of stress and encounter distress in coping with the pressures related to academic assignments and balancing their mental wellbeing. Research confirms that it is not the divorce, but constant parental conflicts that creates negative emotional consequences (Kirk, 2002). Literature supports that children and adolescents brought up in single parent families may develop negative effects (Galluzzo, 2012; Majzub and Mansor, 2012; Rende et al., 1993). Nevertheless, some research studies also reveal that positive outcome can be expected if they are provided 
pleasant and harmonious atmosphere (Kelly, 2007). The problem not only affects intellectual potential and academic capability of the learner, but also result in disturbed mental health. Research studies authenticate that marriages ending up in divorce are a painful and stressful event of life for the students and can result in anxiety and depression during and after this complex transition process. Furthermore, they can even experience varying levels of low self-esteem (Bracke et al., 2010). Studies also confirm that parental divorce creates magnitude of problems for youth transiting into matured adulthood phase, which mainly include disturbed physical health, social and relational difficulties, substance abuse, and internalizing and externalizing the problems (Sigal et al., 2012). The apprehensive thoughts revolving in their mind can interfere with their educational performance. There can be several reasons for the interruption of academic performance like impaired concentration in class, fear and insecurity, behavioral problems, withdrawal from classmates, etc. Research endorses that academic performance is affected due to decrease in parental attention. In addition, there will be lack in learning of social skills like conflict resolution due to inappropriate parental role modeling (Amato and Keith, 1991). The result of the study conducted by Guidubaldi reveals that students belonging to divorced parents are much reliant on others and not accepted well among group of friends (as cited in Majzub and Mansor, 2012). Age, gender, and parenting style plays an important role in handling the consequences of parental divorce (Grubb and Long, 2014). Girls are more likely to present behavioral difficulty than boys living with divorce experience (Rende et al., 1993). The above mentioned lines jells with the scenario, where the student was a female, and was having behavioral issues of difficulty in blending up with friends and social gathering.

\section{What can we do as Educators?}

The most important question is how to minimize the post traumatic effects in students undergoing parental marriage split? Equivalent work up from the student and the single parent can bring a change in the mental wellbeing and behavior. The student can be supported under two domains. First, an interventional program and second is parental effort. In interventional program, counselling session could be conducted, where the student can be helped to express anger, settle anxiety, and confusion related to divorce issue (Matthews, 2014). Strengthening students' coping strategies can have a profound stimulus on the mental well being of the student. Assist the student by providing ways to initiate friendship and socialize with friends. Buddying with the peer, with who could recognize and sensitize the classmate's feelings can facilitate the student to verbalize their anxieties. Supporting the student in building the confidence level and self-esteem through constant encouragement and motivation. Classmates should abstain from ridiculing the classmate, who is juggling studies along with significant life stressors (Majzub and Mansor, 2012). In parental effort, the single parent must make the child understand that she or he is loved and cared. Allow them to participate in solving the family problem and matters (Matthews, 2014). Single parent should be encouraged to use positive words and sentences during everyday communication so that they can look forward positively towards life. Moreover, qualitative researches can be conducted to explore the experiences of adolescent students who have been through this terrible chaos in life.

\section{Conclusion}

Experiencing the after-effects of divorce is an immense challenge encountered by the single spouse, children, and adolescents. Parents are not the only ones who are affected, but the entire family is submerged into the traumatic event. It depends on how a person comprehend bitter realities of life to move ahead for a new beginning however, the massive devastation of mental health, selfesteem, and confidence can give rise to psychological and behavioral problems, which may take time to recuperate. It is not only the challenge for the student, but also for the single parent who have to survive with the situation while keeping her mental status intact and in equilibrium.

\section{References}

[1]. Amato, P. R., \& Keith, B. (1991). Parental Divorce and Adult well being: A Metaanalysis. Journal of Marriage and Family, 53(1), 43-58.

[2]. Bracke, P. F., Colman, E., Symoens, S. A., \& Van Praag, L. 
(2010). Divorce, Divorce rates, and professional careseeking for mental health problems in Europe: $A$ crossectional population based study. BMC Public Health, 10(1), 224-235.

[3]. Clair, J. S. (n.d.). The Effects of Divorce on Children and Education. Retrieved from http://www. divorcewizards.com/ The-effects-of-Divorce-on-Children-and-Education.html

[4]. Galluzzo, D. M. (2012). The Academic and Social Impact of Divorce on Early Childhood Students in School (Doctoral Dissertation, Northeastern University). Retrieved from http://hdl. handle.net/2047/d20002769

[5]. Grubb, J., \& Long, T. (2014). Parental Divorce and Student's Academic Achievement. Artifacts, 10, 1-14. Retrieved from https://artifactsjournal.missouri.edu/ 201 4/08/parental-divorce-and-student-academicachievement/

[6]. Kelly, J. B. (2007). Children's living arrangements following separation and divorce: Insights from empirical and clinical research. Family Process, 46(1), 35-52.

[7]. Khan, M. (2013). Psychological Impact of divorce on Pakistani women. In www.blush.com.pk Retrieved from http://blush.com.pk/psychological-impacts-of-divorceon-pakistani-women/

[8]. Kirk, A. (2002). The effects of divorce on young adults' relationship competence: The influence of intimate friendships. Journal of Divorce \& Remarriage, 38(1-2), 6190.

[9]. Kleiveland, B., Natvig, G. K., \& Jepsen, R. (2010). Stress, sense of coherence and quality of life among Norwegian nurse students after a period of clinical practice. PeerJ, 3 , 1-13.

[10]. Majzub, R. M., \& Mansor, S. (2012). Perception and adjustment of adolescents towards divorce. ProcediaSocial and Behavioral Sciences, 46, 3530-3534.

[11]. Matthews, D. W. (2014). Long term effects of divorce on children. North Carolina Cooperative Extention Services. Retrieved from http://www.ces.ncsu.edu/depts/fcs/ pdfs/fcs482.pdf

[12]. Melo, K., Williams, B., \& Ross, C. (2010). The impact of nursing curricula on clinical practice anxiety. Nurse Education Today, 30(8) 773-778.

[13]. Naevdal, F., \& Thuen, F. (2004). Residence arrangements and well-being: A study of Norwegian adolescents. Scandinavian Journal of Psychology, 45(5), 363-371.

[14]. Parsa, N., Yaacob, S. N., Redzuanb, M., Parsa, P., Parsa, B. (2014). Effects of inter-parental conflict on college student's self-efficacy in Hamadan, Iran. Procedia-Social and Behavioral Sciences, 152, 241-245.

[15]. Rende, R. D., Plomin, R., Reiss, D., \& Hetherington, M. (1993). Genetic and environmental influences on depressive symptomatology in adolescence: Individual differences and extreme scores. Journal of Child Psychology and Psychiatry, 34(8), 1387-1398.

[16]. Schulz, M. S., Waldinger, R. J., Hauser, S. T., \& Allen, J. P. (2005). Adolescents' behavior in the presence of interparental hostility: Developmental and emotion regulatory influences. Development and Psychopathology, 17(2), 489-507.

[17]. Sigal, A. B., Wolchik, S. A., Tein, J., \& Sandler, I. N. (2012). Enhancing Youth outcomes following Parental Divorce: A longitudinal study of the effects of the new beginnings program on Educational and Occupational Goals. Journal of Clinical Child \& Adolescent Psychology, 41 (2), 150-165. doi:10.1080/15374416.2012.651992

[18]. Storksen, I., Roysamb, E., Gjessing, H. K., Moum, T., \& Tambs K. (2007). Marriages and psychological distress among adult offspring of divorce: A Norwegian study. Scandinavian Journal of Psychology, 48(6), 467-476. 


\section{ABOUT THE AUTHOR}

L. Akber Cassum is working as a Senior Instructor at Aga Khan University School of Nursing and Midwifery (AKUSONAM), Pakistan. She did her Masters of Science in Nursing, Post RN - Baccalaureate of Science in Nursing, and Diploma in Nursing from Aga Khan University School of Nursing and Midwifery. She teaches undergraduate nursing courses, such as Culture, Health and Society Course at the same institution. Her research interest, includes Critical Care Nursing (CCN), Cardiac Nursing, Education, and Geriatric Nursing. 